\title{
Variation of qualitative and quantitative traits in day old chick crossbred of Bangkok and Lohman laying hens
}

\author{
Yuli Frita Nuningtyas ${ }^{1,2}$, Muhammad Halim Natsir $^{{ }^{*}}{ }^{*}$, Veronica Margaretha Ani Nurgiartiningsih ${ }^{1}$, \\ Suci Puji Lestari ${ }^{3}$, and Muhamad Nadhif Athariq ${ }^{4}$ \\ ${ }^{1}$ Lecture Faculty of Animal Science, Universitas Brawijaya, Malang 65145, Indonesia \\ ${ }^{2}$ Doctoral student, Faculty of Animal Science, Universitas Brawijaya, Malang 65145, Indonesia \\ ${ }^{3}$ Magister student, Faculty of Animal Science, Universitas Brawijaya, Malang 65145, Indonesia \\ ${ }^{4}$ Bachelor student, Faculty of Animal Science, Universitas Brawijaya, Malang 65145, Indonesia
}

\begin{abstract}
The purpose of this research was to evaluate the body weight based on feather color and shank color in one-day-old (DOC) crossbred of Bangkok and Lohmann laying hens. The research material used was 373 Crossbred Day-Old Chick (DOC). The variables measured were body weight as quantitative traits, therefore feather and shank color as qualitative traits. The results showed that the feather color of Crossbred chicken varied, namely brown, grey, white, yellow, and black, with a percentage of $17.69 \%, 1.87 \%, 6.87 \%, 42.62 \%$, and $30.83 \%$, respectively. The shank colors were yellow and black, with a rate of $67.56 \%$ and $32.42 \%$, respectively. The mean body weight for brown, grey, white, yellow, and black feather color was $40.12 \pm 4.38 \mathrm{~g} ; 42.43 \pm 2.76 \mathrm{~g} ; 40.65 \pm$ $3.03 \mathrm{~g} ; 39.82 \pm 3.38 \mathrm{~g}$; and $39.61 \pm 3.67 \mathrm{~g}$, respectively. The analysis showed that body weight was not different between feather colors. The highest percentage of color for feather and shank was yellow. The quantitative traits measured in crossbred DOC of Bangkok and Lohmann were above the DOC national standard. The results showed that the dominant qualitative trait in Crossbred chicken for feather color was yellow at $42.62 \%$, shank color was yellow at $67.56 \%$.
\end{abstract}

\section{Introduction}

Bangkok chicken is the local chicken family because it has long adapted to the environment in Indonesia and is cultivated by the Indonesian people. Bangkok chicken is usually used as a male because it has various features; a slim body shape and high fighting endurance. Laying Lohmann chickens is a potential egg-producing breed; the egg productivity is relatively high, around $60-70 \%$. Crossed chicken is a local Indonesian chicken from a cross between a Bangkok male and a laying Lohmann hen.

Qualitative properties are traits that cannot be measured but distinguished [1]. The qualitative properties can be classified into one or more groups, and the groupings are distinctly different from each other. This difference phenotypic in the population is

\footnotetext{
* Corresponding author: emhanatsir@ub.ac.id
} 
important to evaluate because it provides crucial information for improving and developing an effective breeding program. Qualitative characteristics will be affected in the adaptation and suitability of livestock to their habitats, especially in extreme tropical. For example, consumer preference of the color feathers laying hens is brown-black, white with black spots, and white had a percentage of $20 \%, 16.7 \%$, and $46.7 \%$, respectively, while the female chickens were $50 \%$ and $23.3 \%$ for black and grey feather. Permadi et all., [2] reported that $73,3 \%$ of consumers prefer chicken with a combination color of red and black feathers. Feather color and shank color are used as trademarks that can be used to increase consumer preferences for crossbred chickens.

Quantitative properties, including body weight, chest circumference, and DOC shank length, are measures of crossbreeding chicken productivity. Body size is essential because it is a good indicator and has a reasonably close correlation value with live weight parameters [3]. Therefore, one primary research to explore genetic information is a phenotypic observation by observing feather color and measuring body weight, chest circumference, and shank length.

This study aims to determine the quantitative (bodyweight) and qualitative (feather color and shank color) characteristics of day-old crossbreed. The results of this study are expected to provide information regarding the optimal standard of crossed DOC chickens in terms of feather color, shank color, and body weight.

\section{Materials and methods}

This research was conducted in Berline Farm, Jl. Maguan No.11, Darungan Maguan, Maguan, Ngajum District, Malang, East Java started from March 16 to May 14, 2021.

\subsection{Materials}

The material used in this research was 373 crossbreed DOC chickens without sex selection (unsexed). The tools and materials used during the study were: DOC box, measuring tape, digital scales, stationery, and calliper.

\subsection{Methods}

The method used in this study was a field experiment and observation by measuring body weight, feather color and shank color of DOC Crossed chickens. Samples were selected by healthy DOC, consisting of standing straight, dry hair, bright eyes, and not wet nose.

1. Body weight

Body weight were carried out on hatched DOC using a digital scale.

2. Feather color

Qualitative data collection is carried out by observing and taking pictures to feather color

3. Shank color

Qualitative data collection is carried out by observing and taking pictures to shank color. 

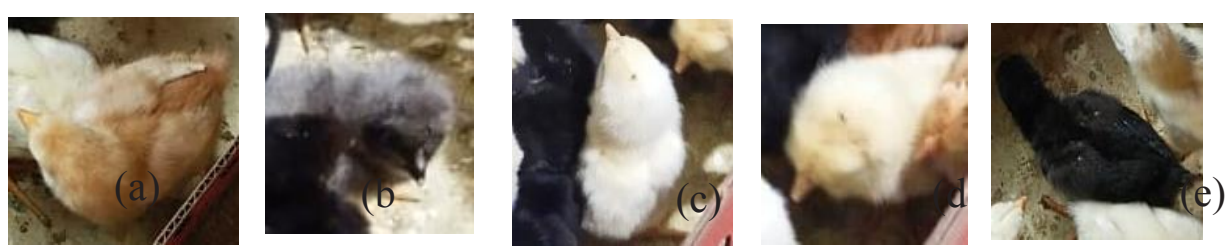

Fig. 1. Color of the feather.

(a) brown; (b) grey; (c) white; (d) yellow; (e) black
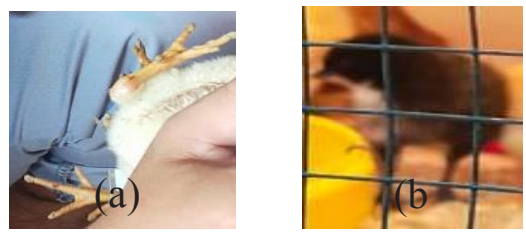

Fig. 2. Color of crossbred shank.

(a) yellow; (b) black

\subsection{Data analysis}

Qualitative trait data in the form of feather color and shank color were analyzed descriptively based on the frequency of the phenotype. The frequency of feather color and shank color is calculated based on the number of phenotypes that appear divided by the total number of individuals observed multiplied by $100 \%$ [4]. The formula is as follows

$$
\text { Frequency Phenotype } A=\frac{\text { number of chicken trait } A}{n} \times 100 \%
$$

Qualitative data of DOC were analyzed based on feather color and shank color. The data were analyzed using one-way analysis of variance (One Way Anova) with the Completely Randomized Design (CRD) method with the following mathematical formula:

$$
\mathrm{Yij}=+\mathrm{i}+\mathrm{ij}
$$

$Y i j=$ the value of observations on the color of the feathers $\mathrm{i}$ repetition $\mathrm{j}$

$\mu=$ general mean

$\mathrm{i}=$ effect of $\mathrm{i}$ feather color

$\mathrm{ij}=$ test error (error) on feather color 


\section{Results and discussion}

\subsection{Color percentage of DOC crossbred}

The color of feathers in poultry varies greatly; the pattern of feather color in chickens is one of the main factors determining the identification process [5]. Based on the research data, the percentage of DOC feathers of Crossed chickens was obtained as presented in Table 1.

Table 1. Color percentage of DOC crossbred

\begin{tabular}{|l|c|c|}
\hline Feather color & $\mathbf{N}$ & Percentage (\%) \\
\hline brown & 66 & 17,69 \\
\hline grey & 7 & 1,87 \\
\hline white & 26 & 6,97 \\
\hline yellow & 159 & 42,62 \\
\hline black & 115 & 30,83 \\
\hline total & 373 & 100 \\
\hline
\end{tabular}

The results showed that the feather color of the crosses varied, namely brown, gray, white, yellow, and black, with a percentage of $17.69 \%, 1.87 \%, 6.87 \%, 42.62 \%$, and $30.83 \%$. Mahmudi [6] states that crossbred chickens have non-uniform feather colors; brown, black, and white. The non-uniform coat color of the crossbred chicken is probably influenced by the feather color of the parents, namely Bangkok chickens, which have a dominant black coat color, and Lohman Brown laying hens which have brown feathers. In contrast, inherited the white color from the elder Lohman Brown. Thus, the appearance of coat color is determined genetically by either dominant or recessive genes. Edowai [1] states that the color of the feathers of male free-range chickens has various colors: plain white, colored Columbian patterns with glittering gold feathers, colored Columbian patterns with gold and silver feathers, while females have striated feather colors, Columbian type colored patterns with glittering gold feathers, and plain black.

Based on the frequency of appearance of color in crossbreed chickens, it is known that the yellow and black colors show a high percentage, namely $42.62 \%$ and $30.83 \%$, respectively, due to the use of Bangkok males, which have colored and black feathers of $70 \%$ and $25 \%$, respectively. The highest percentage of coat color is yellow fur $(42.62 \%)$ which follows DOC Lohmann Brown's coat color, which is also yellow. It was supported research by Sitanggang [4] that the color of Bangkok chicken feathers is $99.20 \%$ colored.

The color of the feathers of this Crossed chicken is different from that of the Gaok chicken as stated by Sartika, [7] that the specific characteristic of the Gaok chicken is the color of the female feathers varies with a black and white striated neck. The color of the rooster's feathers is more uniform; it has a greenish base color with silver-yellow covering and neck feathers, black-yellow-green tail feathers (wido). It was because of the genetic difference between the Cross and Gaok chickens. The feather color of Lohman laying hens showed more dominant than bangkok. 


\subsection{DOC crossbred based on shank}

The different color of the shank is caused by the presence of various pigments [2]. Based on the research data, the percentage of DOC shank color of Crossed chickens was obtained as presented in Table 2 .

Table 2. Shank color percentage of DOC crossbred

\begin{tabular}{|l|c|c|}
\hline Shank color & N & Persentase (\%) \\
\hline Yelow & 252 & 67,56 \\
\hline Black & 121 & 32,43 \\
\hline total & 373 & 100 \\
\hline
\end{tabular}

The results showed that the color of the crossbreed chicken shank varied, yellow and black, with a percentage of $67.56 \%$ and $32.42 \%$, respectively. According to the opinion of Edowai [1] showed that the colors of the free-range chicken shank are white, yellow, black, and gray. Ikasari [8] showed that the color of Kedu chicken shank is white or yellow, sometimes it is black and has a fairly high egg production, and also the opinion of Sartika [7] which states that the color of the Gaok chicken shank is yellow or white.

The highest percentage of shank color is owned by yellow $(67.56 \%)$ because most Bangkok chickens used as males have yellow shank color. Sitanggang [4] states that Bangkok chickens have a yellow shank as much as $69.05 \%$, which has a yellow shank color. One of the factors that cause yellow shank in crossbreed chickens is the lack of melanin in the outer skin. This is in accordance with the opinion of Amlia [9] that the yellow shank color is caused by a lack of melanin content in the dermis (albino) layer. Gene of lohman laying hens more dominant than bangkok chicken, it can be shown in the shank color of crossbreed chicken.

\subsection{Bodyweight of DOC crossbred based feather color}

DOC body weight is also known as hatching weight. Lestari [10] stated that body weight is influenced by the quality and quantity of feed consumed. Therefore, the amount of feed consumption will have an effect on the resulting body weight gain. Nutrients in the feed are balanced and sufficient to promote the growth of chickens. Based on data analysis, the average and coefficient of body weight diversity of Crossed chickens were obtained as presented in Table 4. 
Tabel 3. Average value $(\overline{\mathbf{X}})$, Standart deviation (SD) dan Coefficient of diversity (KK) DOC crossbred body weight

\begin{tabular}{lccc}
\hline \multirow{2}{*}{ Feather color } & $\mathbf{N}$ & $\overline{\boldsymbol{X}} \pm \mathbf{S D}$ & KK (\%) \\
\cline { 3 - 3 } & & $\mathrm{g} / \mathrm{bird}$ & \\
\hline brown & 66 & $40,12 \pm 4,38$ & 10,91 \\
grey & 7 & $42,43 \pm 2,76$ & 6,50 \\
white & 26 & $40,65 \pm 3,03$ & 7,45 \\
yelow & 159 & $39,82 \pm 3,38$ & 8,49 \\
black & 115 & $39,61 \pm 3,67$ & 9,27 \\
\hline total & 373 & $40,52 \pm 3,44$ & 8,53 \\
\hline
\end{tabular}

Based on the analysis of variance, the body weight did not differ between coat colors $(P$ $>0.05)$. The difference in body weight between coat colors comes from elders who have uniform body weights. The results showed that the average body weight of DOC crosses was $40.52 \pm 3.44 \mathrm{~g} / \mathrm{bird}$. This is referred to Trisiwi's [11] which states that Super free-range chickens have faster growth than local free-range chickens. The bodyweight of DOC Crossed chickens was $37 \mathrm{~g} / \mathrm{bird}$ until harvest time (60 days) with a weight of $0.9 \mathrm{~kg} / \mathrm{bird}$. The results of the study are also higher than the provisions in the Regulation of the Minister of Agriculture Number: 49/Permentan/OT.140/10/2006, that the DOC body weight of Crossed chickens is 29-36 g/bird and minimum DOC weight in hatching is $35 \mathrm{~g}$ based on the SNI 7353-1:2019. The cross-program caused the results of this research applied using Bangkok chicken and selected Lohman chickens.

The bodyweight of DOC Crosses from this study was higher than the DOC of freerange chicken. Kususiyah (2011) reported that crossbreed was $25.75 \mathrm{~g}$, and the Kedu chicken from the analysis of [10] that is equal to $33.02 \mathrm{~g} / \mathrm{bird}$. Due to better management and comes from superior elders.

\section{Conclusion}

The conclusion of this research showed that the qualitative traits of the DOC has the variety feather color with the highest percentage of feather color is yellow, shank color is black and yellow, therefore the quantitative traits of DOC crossbred has the higher body weight than the national standard.

\section{References}

1. E. Edowai, E. L. S. Tumbal, F. M. Maker. Jurnal Fapet ternak. 4,50-58 (2020)

2. A. N. N. Permadi, E. Kurnianto, Sutiyono. Jurnal Peternakan Indonesia. 22, 11-20 (2020)

3. A. Suparyanto, H. Martojo, P.S. Hardjosworo, et all. Jurnal Ilmu Ternak dan Veteriner. 9: 87-97 (2004)

4. E.N. Sitanggang, Hasnudi, Hamdan. Jurnal Peternakan Integratif. 3, 167-189 (2015)

5. A.G. Nataamijaya. Buletin Plasma Nutfah. 11, 1-6 (2005)

6. M. Mahmudi. Doctoral dissertation, Universitas Brawijaya (2019)

7. T. Sartika, S. Sulandari, M.S.A. Zein, Pusat Penelitian dan Pengembangan Peternakan, Bogor (2006)

8. N. Ikasari, E. Kurnianto, I. Sumediana. Animal Agriculture Journal. 1, 198-207 (2012) 
9. M.A. Amlia, R. Pagala, JITRO. 3, 31-39 (2016)

10. Lestari, R. Maskur, Jan, JITPI. 6, 24-32 (2020)

11. H.F. Trisiwi, Jurnal Ilmiah Peternakan Terpadu. 4, 256-262 (2016) 